\title{
Rare Causes of Respiratory Insufficiency in Newborns
}

\author{
Jana BRUCKNEROVÁ ${ }^{1}$, Jozef BABALA ${ }^{3}$, Eduard UJHÁZY ${ }^{4}$, Mojmír MACH $^{4}$, Ivo \\ JURÁNEK ${ }^{4}$, Ingrid BRUCKNEROVÁ ${ }^{2}$
}

${ }^{1}$ Faculty of Medicine, Comenius University in Bratislava, Slovak Republic, ${ }^{2}$ Neonatal Department of Intensive Medicine, Comenius University in Bratislava and National Institute of Children's Diseases, Slovak Republic, ${ }^{3}$ Department of Paediatric Surgery Comenius University in Bratislava and National Institute of Children's Diseases, Slovak Republic, ${ }^{4}$ Centre of Experimental Medicine, Slovak Academy of Sciences, Slovak Republic

Received October 6, 2020

Accepted November 5, 2020

\begin{abstract}
Summary
Congenital lung masses (CLM) the rare group of causes of acute respiratory insufficiency (RI) in newborns include congenital airway pulmonary malformation (CAPM), congenital overinflation, bronchopulmonary sequestration, and bronchial atresia. The presenting group consists of 13 newborns who were admitted to the Neonatal Department of Intensive Medicine (NDIM) during January $1^{\text {st }}$ 2015-December $31^{\text {st }} 2019$ (8 males, 5 females, 2 premature/11 term newborns, spontaneous delivery: 2, caesarean section: 11) with positive prenatal diagnosis of CAPM in all cases. In 2 cases prenatal intervention was performed (drainage of the amniotic fluid, attempt of thoracentesis). Signs of acute RI immediately after delivery were seen in 5 newborns. Postnatal echocardiographic investigation confirmed the presence of increased pulmonary pressure in 8 patients, no patient had congenital heart abnormality. A thorax x-ray was positive also in asymptomatic patients. Computed tomography in patients brought detailed information about the position, size and character of CAPM. Six patients underwent surgery. In $15.4 \%$ right lungs were affected by cystic malformation and in $23 \%$ left lungs were affected. A final diagnosis of CAPM was confirmed in 5 patients using histopathologic examination. Multidisciplinary cooperation during prenatal as well as postnatal period is necessary.
\end{abstract}

\section{Key words}

Congenital lung masses - Congenital pulmonary airway malformation • Newborn

\section{Corresponding author}

I. Brucknerová, Neonatal Department of Intensive Medicine Comenius University in Bratislava, National Institute of Children's Diseases, Limbová 1, 83340 Bratislava, Slovak Republic. E-mail: ingrid.brucknerova@fmed.uniba.sk

\section{Introduction}

The development of the respiratory system is intricately linked to the development of the digestive system. The respiratory system begins to form in the 4th week of gestation from the ventral wall of the foregut intestine. From the epithelium the laryngotracheal groove is formed, which is connected to the foregut. It gradually grows in a caudal direction and by means of a tracheoesophageal septum, the anterior intestine is divided into oesophagus and ventrally placed trachea with bronchopulmonary buds. As a result of this, the origin of the breathing tube is separated from the digestive tract. The epithelium of the airways and the respiratory part of the lungs arises from the entoderm. The mesenchyme form ligaments (and connective tissue proper in mucosa layer), smooth muscle, and blood vessels of the respiratory system (Kapeller and Pospíšilová 1991, Sadler, 2011, Mráz et al. 2015).

Several phases in the process of lung differentiation are distinguished (Sadler 2011, Bouchard 2018). For the 1 st embryonic stage (3rd - 5th week of embryonic age) there is the typical formation of laryngotracheal diverticulum with subsequent formation of primary, secondary and tertiary bronchi and trachea. During the 2nd pseudoglandular stage (weeks 6 - 16) further branching of the terminal respiratory tree up to the terminal bronchioles is present. Respiratory alveoli and bronchioles are not yet formed. From prenatal weeks 5 to 17, the lungs look like a tubuloacinar gland with epithelial tubes that branch into the surrounding 
mesenchyme (Berrocal et al. 2004). This period is characterized by the formation of an immature neural network. Type 2 pneumocytes appear (Bouchard, 2018). During the 3rd canalicular phase (weeks 16-26) each terminal bronchiole is divided into 2 or more respiratory bronchioles, and these are divided into 3 to 6 alveolar ducts. Respiratory bronchioles are more vascularized. Differentiation of the cuboidal epithelium into type I and type II cells, as well as the surfactant synthesis appears. The 4th phase is the saccular stage (26th week until delivery) presented with formation of widened airspaces and termed saccules that are formed on peripheral airways, to which capillaries are attached. Thinning of the connective tissue between the airspaces is detectable. Primitive alveoli are covered with type 1 and type 2 pneumocytes, maturation of the surfactant system is presented. After 28 weeks of gestation, significant reduction in mesenchymal tissue occurs, the distal saccules are divided, and their walls become thinner (Berrocal et al. 2004). The surfactant is detectable in amniotic fluid. An extracellular matrix is formed (Bouchard, 2018). The 5th phase is called alveolar stage (8th month of development to childhood: 7th - 10th year) with formation of mature alveoli and tight alveolar membrane. Alveoli are divided until there are 300 million of them. They reach this number in the 8th year of life (Berrocal et al. 2004).

Congenital airway pulmonary malformations, formerly referred to as congenital cystic adenomatoid pulmonary malformation (CCAPM), are rare developmental abnormalities of the lower respiratory tract. The incidence of congenital pulmonary malformations is in the range of 30-42 cases per 100,000 population, the incidence of CCAPM of 1: 10,000 - 1: 35,000 births (Costa et al. 2008).

Many studies have examined the effect of keratinocyte growth factor, fibroblast growth factor-10, glial cell-derived neurotrophic factor, and failure of "communication" between endoderm and mesoderm tissue, and an imbalance between cell proliferation and apoptosis during organogenesis (Berrocal et al. 2004). Swarr and his co-authors suggest three aetiologies (Swarr et al. 2018). Results from experimental work on animals can also help us to better understand the changes that occur during lung development (Piešová and Mach 2020).

CCAPM was first described in 1949 (Ch'In and Tang 1949). Stocker divided them into three main types (Stocker et al. 1977). According to Adzick, two types of lung lesions are distinguished (Adzick et al. 1985). The new classification specifies the place of origin of congenital airway malformations (Andrade et al. 2011). Currently, a classification of 5 forms is used (Oerman et al. 2019, Egloff and Bulas 2020).

Cystic findings in the lungs are usually detected at $20^{\text {th }}$ week of gestation (Witlox 2019). The fastest change in the size of cystically altered lungs is achieved between the $20^{\text {th }}$ and $26^{\text {th }}$ gestational week. The largest dimension is usually confirmed in the $25^{\text {th }}$ gestational week. After this period, either a slow growth phase occurs or even a spontaneous regression may occur. Macrocystic lesions have been found to grow more slowly compared to microcystic or solid lesions. The probability of developing hydrops is not different (Morini et al. 2018). A necessary part of the examination of the newborn is detection of the presence of associated congenital anomalies (Harmath et al. 2007, Cavoretto et al. 2008).

The finding in the lungs affects the signs of respiratory insufficiency (RI) immediately after delivery. Majority of cases are presented after neonatal period. Postnatal examination methods include native chest X-rays and computed tomography (CT). High-resolution CT makes it possible to differentiate microcystic from macrocystic lesions. CT with the administration of a contrast substance is used for exclusion of pulmonary sequestration. Magnetic resonance imaging (MRI) clarifies the more detailed characteristics of the lesion. Sonography (brain, urinary system, heart) for associated congenital anomalies and for measurement of a pressure in lungs, genetic testing is recommended. New diagnostic options include ultrasound examination of the lungs.

Childcare begins at the stage of prenatal development (corticoids, surgery: decompression, resection, thoracocentesis, aspiration, continual drainage, fetal tracheobronchoscopy) (Witlox et al. 2011, Chon et al. 2018). Surgical resection prevents infections and malignant transformation. Childbirth management as well as care in the immediate postpartum period always requires multidisciplinary cooperation in a highly specialized medical facility.

The aim of presented work is to analyze prenatal and postnatal course, diagnostic and therapeutical attitudes.

\section{Methods}

Retrospective analysis of newborns admitted to the NDIM during January 1, 2015 - December 31, 2019 with prenatal suspicion of congenital airway pulmonary malformation. The group of patients consisted of 13 newborns. 
Table 1a. Characteristic of the patients (1-7).

\begin{tabular}{|c|c|c|c|c|c|c|c|}
\hline \multirow[t]{2}{*}{ Patient } & \multirow{2}{*}{$\begin{array}{l}\text { Prenatal } \\
\text { admin. of } \\
\text { corticoids }\end{array}$} & \multirow{2}{*}{$\begin{array}{c}\text { Age and clinical } \\
\text { condition at admission to } \\
\text { NDIM }\end{array}$} & \multicolumn{5}{|c|}{ Characteristic of the patient } \\
\hline & & & $\mathbf{A F}$ & Delivery & $\begin{array}{c}\text { BW } \\
(\mathrm{g})\end{array}$ & $\begin{array}{c}\text { BL } \\
(\mathrm{cm})\end{array}$ & AS \\
\hline 1 & without & $\begin{array}{c}\text { - } 1 \text { hour } \\
\text { - on spontaneous } \\
\text { ventilation, } \mathrm{FiO}_{2} 0.21\end{array}$ & clear & $\begin{array}{l}\text { 38+4 g. w., } \\
\text { elective section } \\
\text { from CLM }\end{array}$ & 3146 & 49 & $\begin{array}{c}9 / 9 / 1 \\
0\end{array}$ \\
\hline 2 & without & $\begin{array}{c}\text { - } 6 \text { days } \\
\text { - on spontaneous } \\
\text { ventilation, } \mathrm{FiO}_{2} 0.21\end{array}$ & clear & $\begin{array}{l}38 \text { g. w., section } \\
\text { from the } \\
\text { orthopaedic } \\
\text { indication of the } \\
\text { mother (condition } \\
\text { after pelvic } \\
\text { fracture) and } \\
\text { CLM }\end{array}$ & 3440 & 50 & $8 / 9$ \\
\hline 3 & complete & $\begin{array}{l}\text { - } 2 \text { hours } \\
\text { - before transport: } \\
\text { orotracheal intubation, } \\
\text { ventilatory support, } \\
\mathrm{FiO}_{2} 0.70 \\
\text { - after admission: } \\
\text { ventilatory support }\end{array}$ & clear & $\begin{array}{l}38 \mathrm{~g} . \mathrm{w} ., \text { section } \\
\text { from pelvic } \\
\text { position and } \\
\text { congenital lung } \\
\text { malformation }\end{array}$ & 2830 & 49 & \\
\hline 4 & complete & $\begin{array}{c}\text { - } 7 \text { days } \\
\text { - on spontaneous } \\
\text { ventilation, } \mathrm{FiO}_{2} 0.21\end{array}$ & clear & $\begin{array}{l}38 \text { g. w., planned } \\
\text { section }\end{array}$ & 3200 & 49 & $\begin{array}{c}10 / 1 \\
0\end{array}$ \\
\hline 5 & complete & $\begin{array}{l}\text { - 3rd day (hydrops, } \\
\text { syndrome of blue face and } \\
\text { upper vena cava; } \\
\text { petechiae; surfactant) } \\
\text { - after admission: inotropic } \\
\text { support (Dobutamine), } \\
\text { ventilatory support, } \\
\mathrm{FiO}_{2} 0.80\end{array}$ & clear & $\begin{array}{l}31+6 \text { g. w., } \\
\text { section due to } \\
\text { preeclampsia }\end{array}$ & 2430 & 40 & $3 / 5 / 5$ \\
\hline 6 & complete & $\begin{array}{c}\text { - } 4 \text { days } \\
\text { - on spontaneous } \\
\text { ventilation, } \mathrm{FiO}_{2} 0.21\end{array}$ & clear & $\begin{array}{c}\text { 38+3 g. w. } \\
\text { spontaneous } \\
\text { vacuum } \\
\text { extraction }\end{array}$ & 3080 & 50 & \\
\hline 7 & $\begin{array}{c}33 \mathrm{~g} . \mathrm{w} . \\
\text { Betamethasone }\end{array}$ & $\begin{array}{c}\text { - } 3 \text { days } \\
\text { - on spontaneous } \\
\text { ventilation, } \mathrm{FiO}_{2} 0.21\end{array}$ & clear & $\begin{array}{l}36+5 \text { g. w. } \\
\text { spontaneous }\end{array}$ & 2800 & 43 & $\begin{array}{c}10 / 1 \\
0\end{array}$ \\
\hline
\end{tabular}

g. w. - gestational week, AF - amniotic fluid, AS - Apgar score, $\mathrm{FiO}_{2}$ - oxygen fraction, g. - gram, cm - centimeter, CLM - congenital lung malformation, admin. - administration, BW - birth weight, BL - birth length, NDIM - Neonatal Department of Intensive Medicine

\section{Results}

The presenting group of patients with positive prenatal diagnosis of CAPM (fetal sonography, MRI) consists of 13 newborns ( 8 males/5 females, 2 premature newborns/11 term newborns, spontaneous delivery: 2, caesarean section: 11) (Table 1a, 1b). In 2 cases prenatal intervention was performed (drainage of the amniotic 
Table 1b. Characteristic of the patients (8-13).

\begin{tabular}{|c|c|c|c|c|c|c|c|}
\hline \multirow[t]{2}{*}{ Patient } & \multirow{2}{*}{$\begin{array}{l}\text { Prenatal } \\
\text { admin. of } \\
\text { corticoids }\end{array}$} & \multirow{2}{*}{$\begin{array}{l}\text { Age and clinical condition } \\
\text { at admission to NDIM }\end{array}$} & \multicolumn{5}{|c|}{ Characteristic of the patient } \\
\hline & & & $\mathbf{A F}$ & Delivery & $\begin{array}{c}\text { BW } \\
(\mathrm{g})\end{array}$ & $\begin{array}{c}\text { BL } \\
(\mathrm{cm})\end{array}$ & AS \\
\hline 8 & complete & $\begin{array}{l}\text { after delivery: condition } \\
\text { after chest drainage, } \mathrm{O}_{2}, \\
\text { intubation, ventilation, } \\
\text { surfactant } \\
\text { time of admission: } 1 \text { hour, } \\
\text { high-frequency ventilation } \\
\text { with } \mathrm{FiO}_{2} 0.99 \text {; continuous } \\
\text { chest drainage; chest X-ray: } \\
\text { left pneumothorax with } \\
\text { transfer of mediastinum to } \\
\text { right hemithorax; intensive } \\
\text { ventilation mode; inotropic } \\
\text { support (Adrenaline); } \\
\text { transfusion of erythrocyte } \\
\text { mass }\end{array}$ & clear & $\begin{array}{l}38 \text { g. w., planned } \\
\text { section due to } \\
\text { macrocystic form }\end{array}$ & 3500 & 49 & $8 / 7 / 6$ \\
\hline 9 & without & $\begin{array}{c}-1 \text { hour } \\
\text { - short time supportive } \\
\text { ventilation, spontaneous } \\
\text { ventilation, } \mathrm{FiO}_{2} 0.21\end{array}$ & clear & $\begin{array}{l}38 \text { g. w., planned } \\
\text { section /CLM }\end{array}$ & 3575 & 52 & $9 / 9$ \\
\hline 10 & without & $\begin{array}{c}-7 \text { days } \\
\text { - on spontaneous ventilation, } \\
\mathrm{FiO}_{2} 0.21\end{array}$ & clear & $\begin{array}{l}38 \text { g. w., planned } \\
\text { section/CLM }\end{array}$ & 3010 & 48 & $9 / 10$ \\
\hline 11 & without & $\begin{array}{c}-3 \text { hours } \\
\text { - on spontaneous ventilation, } \\
\mathrm{FiO}_{2} 0.21\end{array}$ & clear & $\begin{array}{c}39 \text { g. w., planned } \\
\text { section/CLM }\end{array}$ & 3180 & 48 & $10 / 10$ \\
\hline 12 & $\begin{array}{l}\text { complete }+ \\
\text { Betamethason } \\
\text { e }\end{array}$ & $\begin{array}{c}-1 \text { hour } \\
\text { - on spontaneous ventilation, } \\
\mathrm{FiO}_{2} 0.21\end{array}$ & clear & $\begin{array}{l}37 \text { g. w., planned } \\
\text { section /CLM }\end{array}$ & 2800 & 48 & $10 / 10$ \\
\hline 13 & without & $\begin{array}{c}-1 \text { hour } \\
\text { - on spontaneous ventilation, } \\
\mathrm{FiO}_{2} 0.21\end{array}$ & clear & $\begin{array}{l}38+6 \text { g. w. } \\
\text { section }\end{array}$ & 3014 & 50 & $10 / 10$ \\
\hline
\end{tabular}

g. w. - gestational week, AF - amniotic fluid, AS - Apgar score, $\mathrm{FiO}_{2}$ - oxygen fraction, g. - gram, cm - centimetre, CLM - congenital lung malformation, admin. - administration, BW - birth weight, BL - birth length, NDIM - Neonatal Department of Intensive Medicine

fluid, attempt of thoracentesis). Signs of acute RI immediately after delivery in 5 newborns. Postnatal echocardiography confirmed the presence of increased pulmonary pressure in 8 patients, no patient had congenital heart abnormality. A thorax x-ray with the confirmation of the presence of congenital lung masses was positive not only in symptomatic but also in asymptomatic patients (Fig. 2, 3, 5, 6, 7a, 8a, 9a). CT in patients brought detailed information about the character of CAPM (Fig. 1, 4, 7b, 8b, 9b). Six patients underwent surgery. In $15.4 \%$ right lungs were affected by cystic malformation (1 patient: complete lobectomy of the right lower lung lobe, 1 patient: complete lobectomy of the right upper lung lobe). In $23 \%$ left lungs were affected (2 patients: non-anatomical resection of the left upper lung lobe, 1 patient: complete lobectomy of the left lower lung lobe). The final surgical procedure was contraindicated due to haemodynamic instability during 
operation in one patient, only therapeutic drainage of the pleural cavity was performed (Table $2 \mathrm{a}, 2 \mathrm{~b}$ ). No patient had associated malformations. A final diagnosis of

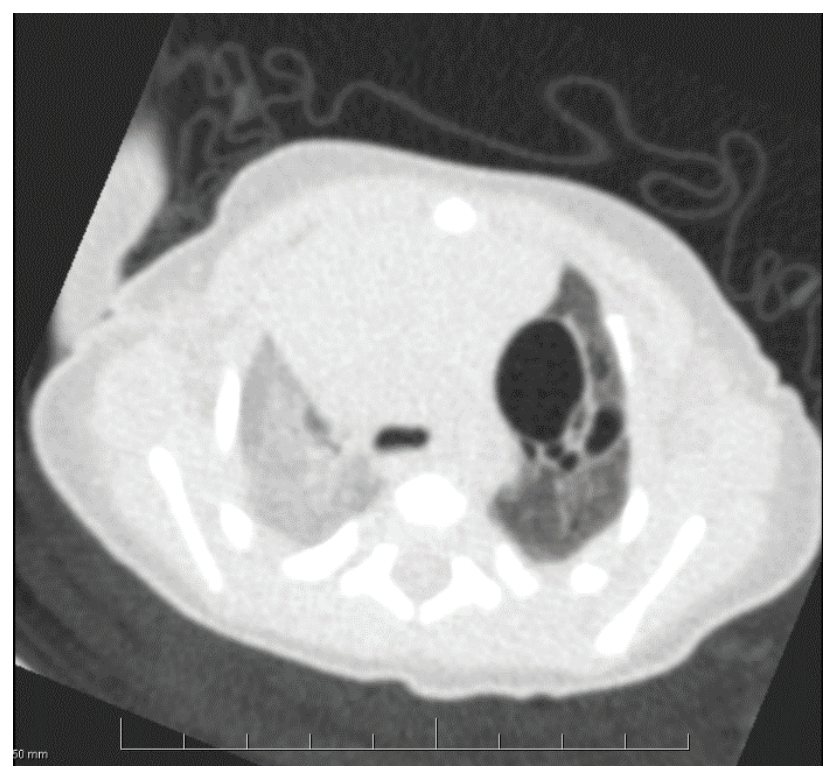

Fig. 1. Patient 2. Computed tomography/angiography. Bilaterally in the range of the lower and middle lobes, on the right and in the upper reduced transparency of the parenchyma. On the left in the range of the upper lobe present emphysematous bulges of various sizes, the largest up to a diameter of $20 \mathrm{~mm}$, the others smaller.

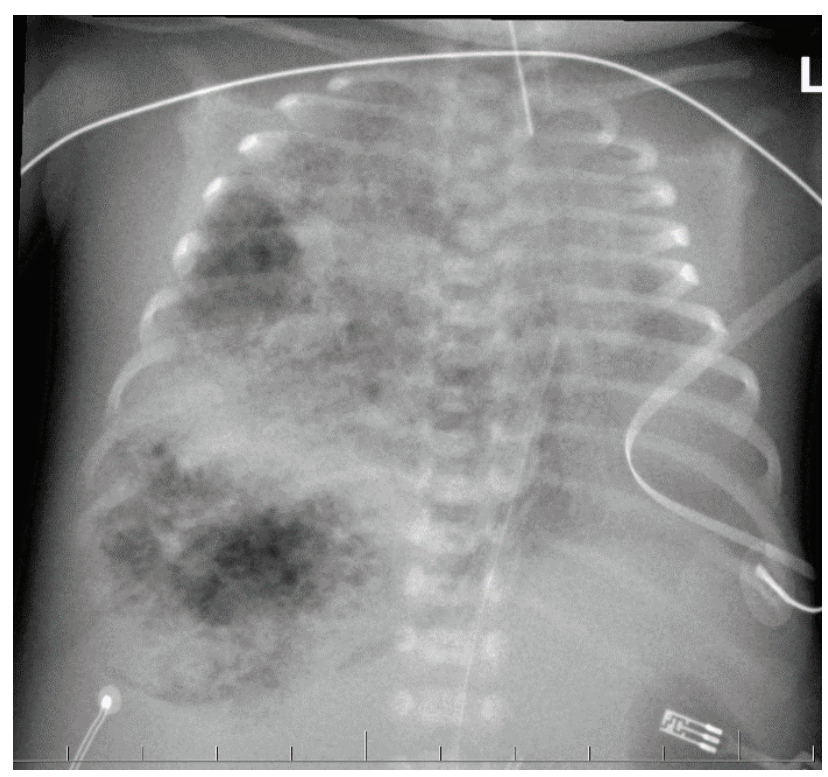

Fig. 3. Patient 5. Native X-ray of the thorax (anterior-posterior view). Both wings without a normal drawing (a markedly spotted, nodular pattern). Right lungs are significantly larger than the left, which are hypoplastic. Mediastinal organs are moved to the left, the border of the heart is out of focus. Various alternating areas of shading and brightening are located in the lungs.
CCAPM was confirmed in 5 patients using histopathologic evaluation.

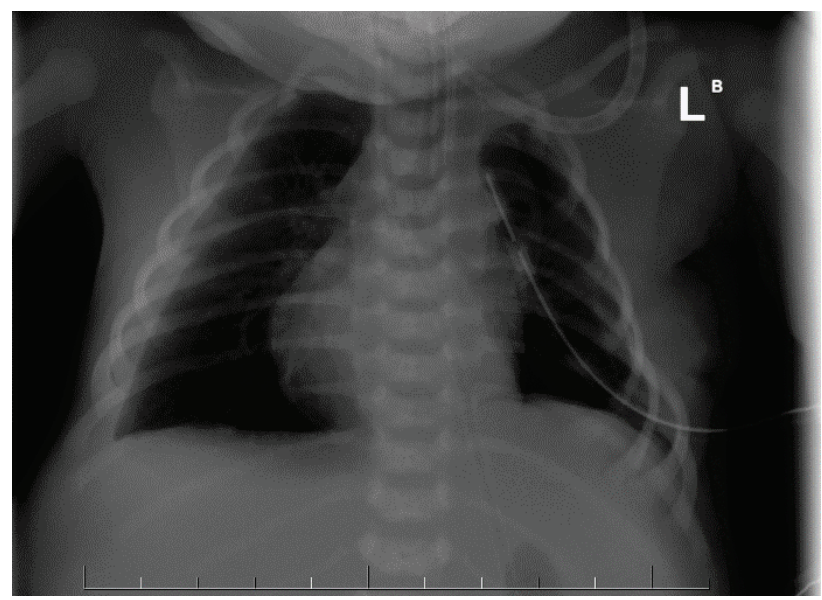

Fig. 2. Patient 3. Native X-ray of the thorax (anterior-posterior view). Reduced respiration area of both wings. Left altered structure and architecture of the lungs, alternating areas of increased and decreased airiness, emphysematous areas - the largest of them in the range of upper and middle lung left field (50×25 mm), smaller emphysematous areas in the area of lower lung field basal and medial. Also present, inhomogeneous, irregular areas of reduced airiness. Pathologically altered left lung with pressure manifestations on the organs of the mediastinum, heart, with their movement to the right and right substernal herniation of the left lung. On the right, the parenchyma is reduced, the hypoplastic whole chest is preserved.

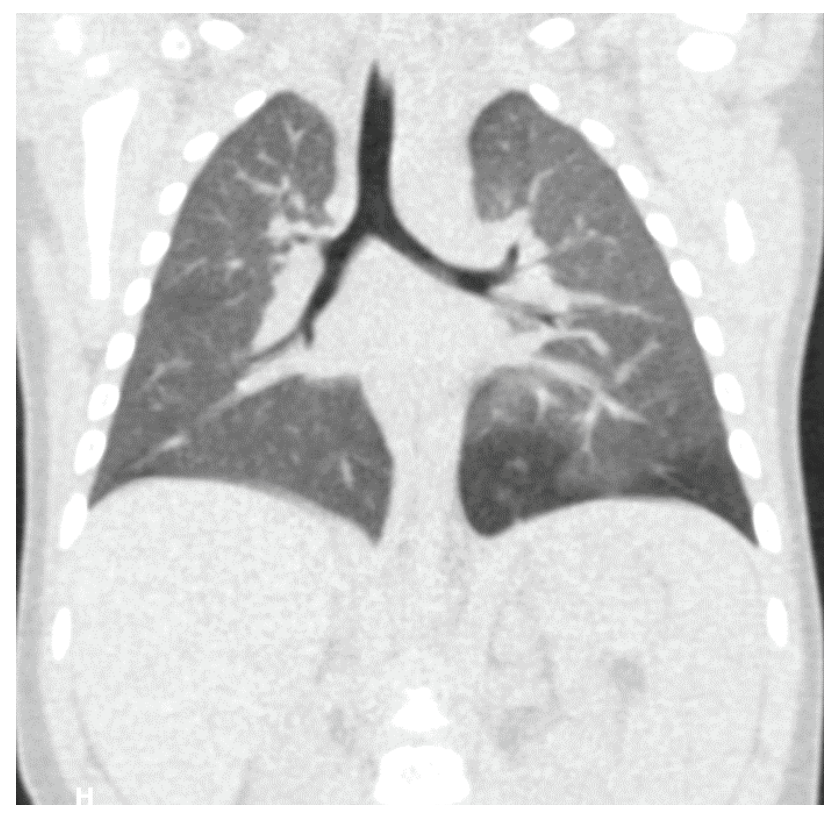

Fig. 4. Patient 6. Computed tomography/angiography. On the left in the lower lung lobe in the segments S7, S8, S9, S10 parenchyma of increased transparency with present microcysts with a diameter of up to $\max 3.2 \mathrm{~mm}$, post-contrast without saturation, without the supply artery, is presented. 


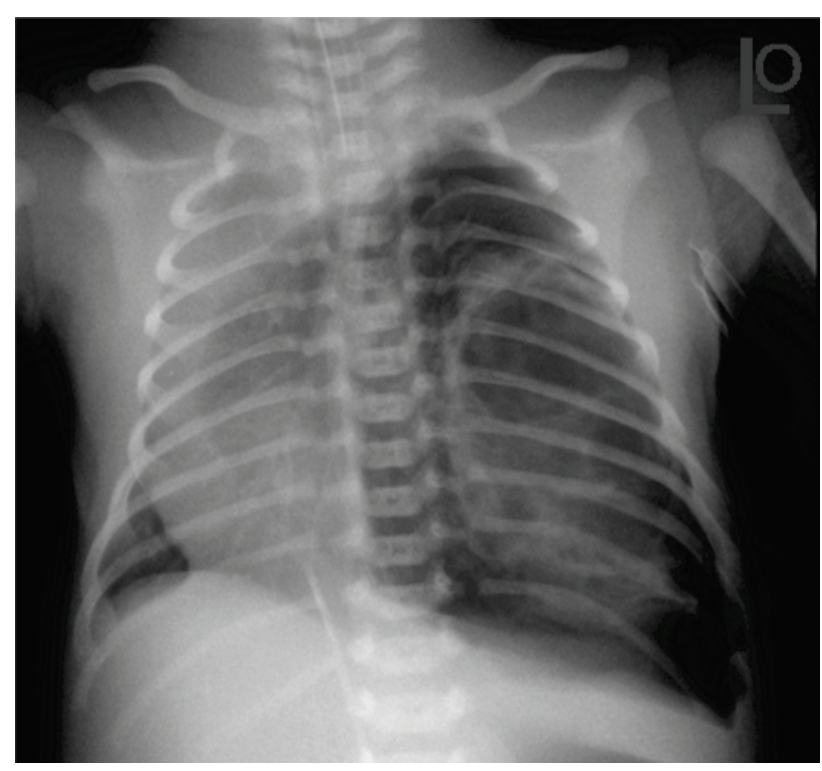

Fig. 5. Patient 8. Native X-ray of the thorax (anterior-posterior view). Increasing the airiness of the left hemithorax in the upper and middle lung field based on macrocystic dysplasia on the left. Mediastinum is dislocated with the shadow of the heart to the right based on macrocystic dysplasia on the left and hypoplasia of the lungs on the right. On the left side an increase in airiness of lung parenchyma without bronchovascular drawing due to the pneumothorax. Hypoplasia of the right wing, moving the mediastinum to the right.

\section{Discussion}

Most patients with congenital pulmonary malformations (CPM) are asymptomatic in the neonatal period. These are about $3 / 4$ patients with a prenatally confirmed diagnosis of CAPM (Swarr et al. 2018). In our group of patients 4 newborns were admitted by the $1^{\text {st }}$ hour of life on spontaneous ventilation, 1 patient by the $3^{\text {rd }}$ hour of life also on spontaneous ventilation, and 5 newborns were admitted after 4 days of life on spontaneous breathing. Three patients were immediately after delivery intubated and put on ventilatory support.

Making differential diagnosis of CPM we excluded diaphragmatic hernia, bronchopulmonary sequester, pulmonary hypoplasia, tracheal atresia, bronchogenic cyst or bronchial stenosis or congenital high airway obstruction syndrome (Bulas and Egloff 2019, D'Eufemia et al. 2016).

Cavoretto et al. 2008 described 170 cases with the CCAPM. In 88 cases the lesion was leftsided, rightsided in 82 newborns. In our group of patients, the prenatal diagnosis of lung pathology was established in $100 \%$. Postnatally we confirmed the prevalence in the left lungs (38\%), in 4 case in right lungs $(30 \%)$, in 2 cases bilateral and in 2 cases the $\mathrm{x}$-ray of the thorax was negative.

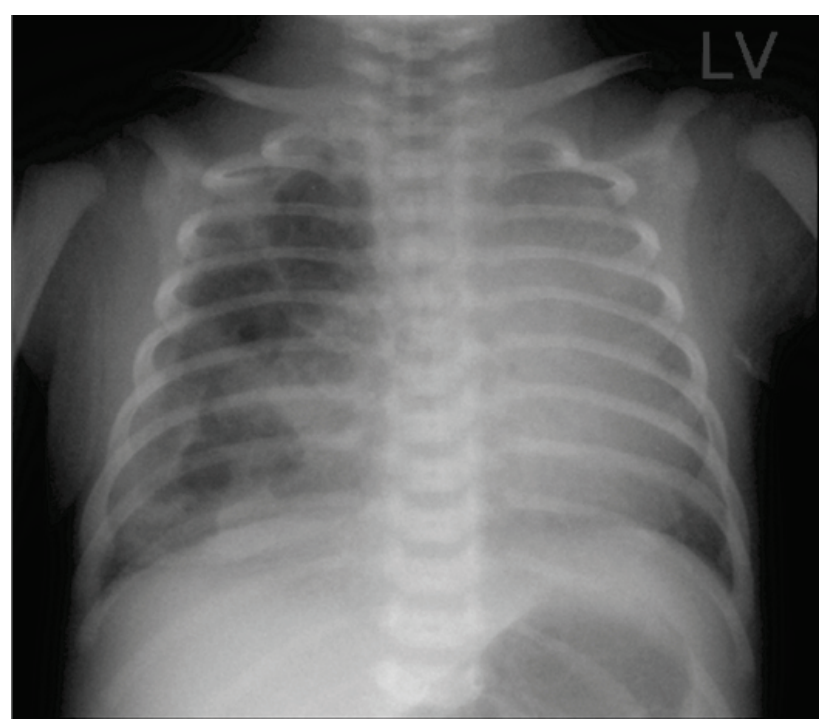

Fig. 6. Patient 9. Native X-ray of the thorax (anterior-posterior view). Inhomogeneous areas of reduced and increased airiness of right lung parenchyma in the sense of congenital cystic malformation of the lungs (cysts with a diameter of 10-28 mm). The left lung parenchyma is covered by shadow of the heart and mediastinum and basal lung parenchyma differentiable. Shadow of the heart and mediastinum with a shift to the left.

The therapeutic approach to patients in the previous period was not uniform. The diagnosis and treatment on our group of patients were proceeded according to the proposed algorithms according to Annunziata et al. 2019 and according to the summary presented in UpToDate 2020 (Egloff and Bulas 2020). Six patients from group underwent surgery. In $15.4 \%$ right lungs were affected by cystic malformation (1 patient: complete lobectomy of the right lower lung lobe, 1 patient: complete lobectomy of the right upper lung lobe). In $23 \%$ left lungs were affected ( 2 patients: non-anatomical resection of the left upper lung lobe, 1 patient: complete lobectomy of the left lower lung lobe). The final surgical procedure was contraindicated due to haemodynamic instability during operation in one patient (patient No 5), only therapeutic drainage of the pleural cavity was performed. In patient No 2 , clinical status during first six days of life was optimal. This child did not have signs of respiratory insufficiency, but extensive findings in the lungs on CT-angiography indicated required surgery on $11^{\text {th }}$ day of life. In this case optimal maturity together with physiological postnatal adaptation did not prevent the newborn surgery of the lungs.

The five patients (patient No 1, 9, 11, 12, 13) did not undergo surgery during the neonatal age. Their clinical condition was adequate and acute surgery was not required. Patient 1 (The control prenatal 

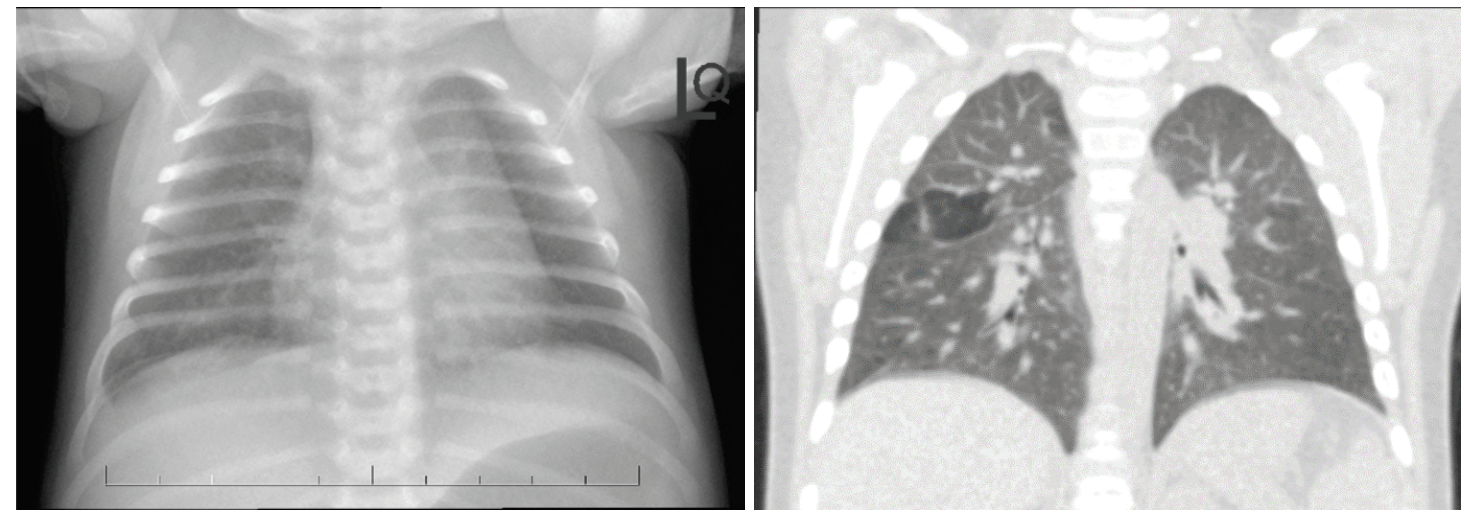

Fig. 7. a) Patient 11. Native X-ray of the thorax (anterior-posterior view). Without unambiguous cystic clarifications, only discreetly indicated small clarifications of the diameter up to $5-6 \mathrm{~mm}$, at the interface of the upper and middle lung field is visible. Mediastinum is extended to the left (thymus), without displacement. b) Patient 11. Computed tomography/angiography. Two areas of slightly

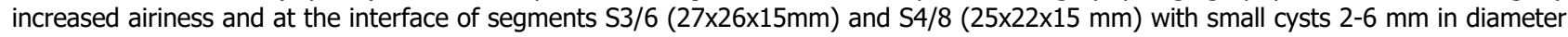
are visible.
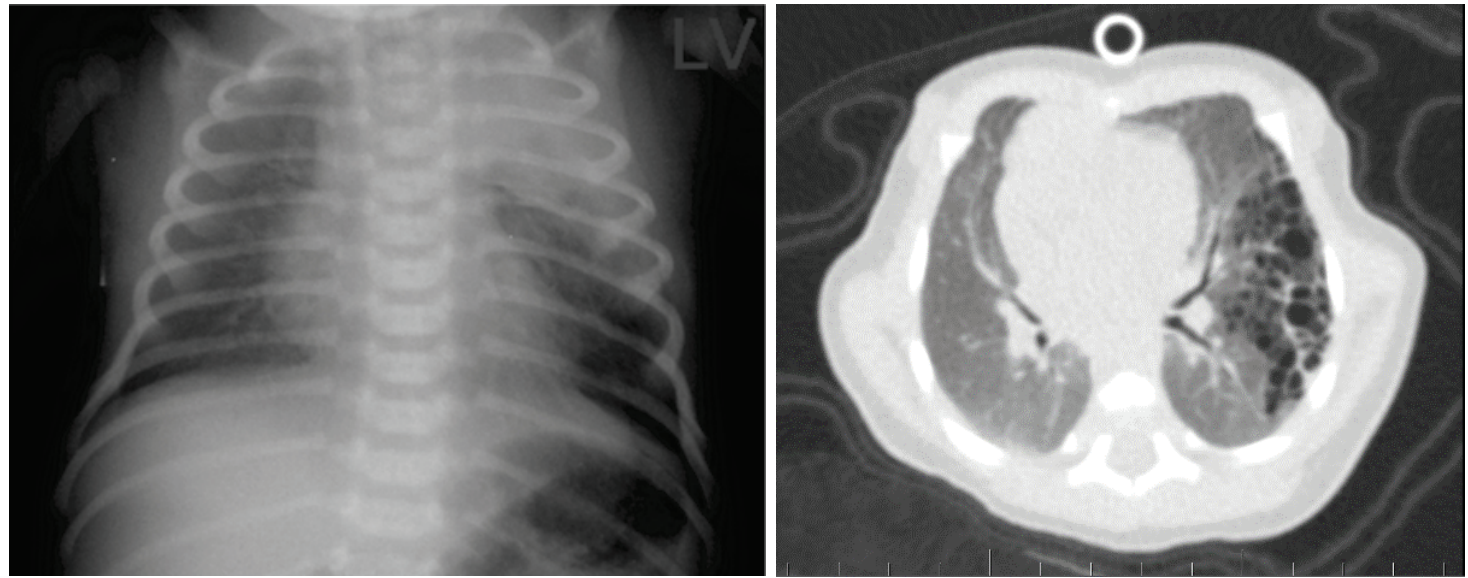

Fig. 8 a) Patient 12. Native X-ray of the thorax (anterior-posterior view). Homogeneous shading of the character of the consolidation of the upper lobe of the left hemithorax, the area of the lower lobe with increased airiness in the area of the external angle. b) Patient 12. Computed tomography/angiography. The aeration of atelectasis in the upper left lobe. The extent of involvement of the lung parenchyma in terms of emphysematous bullae was slightly highlighted in lobes S1, 2, 3 and 6.
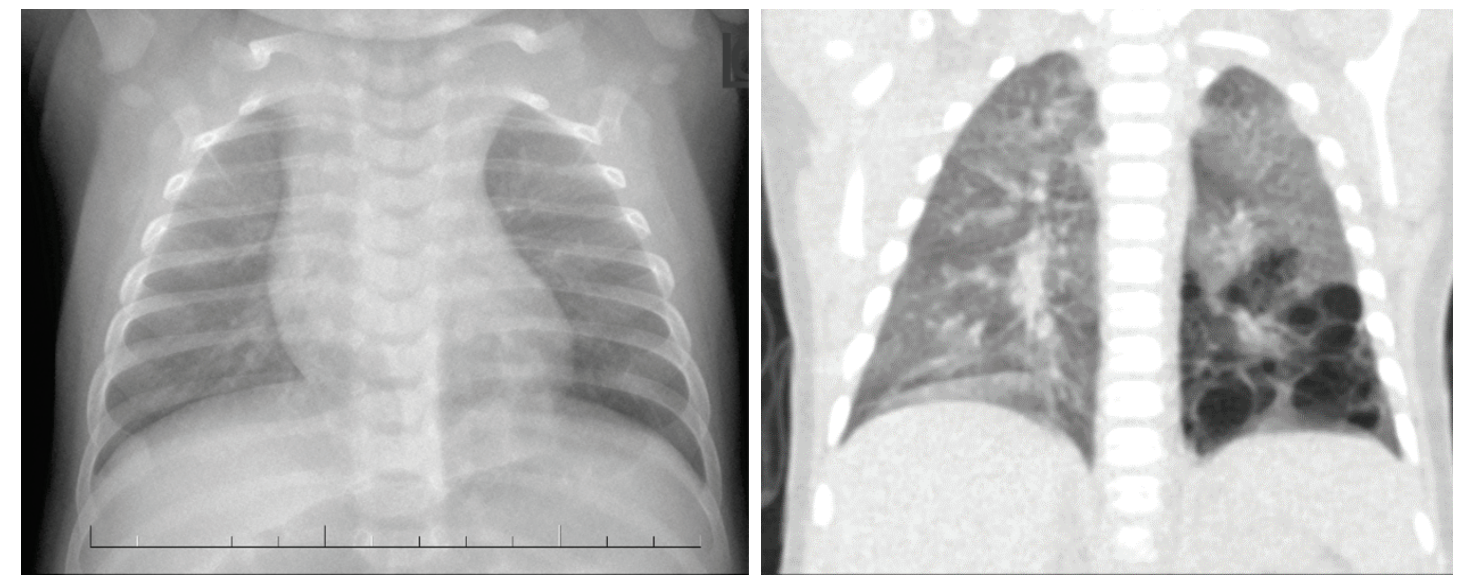

Fig. 9. a) Patient 13. Native X-ray of the thorax (anterior-posterior view). Pulmonary parenchyma without focal changes. On both sides in the lower lung fields bilateral basal increase in airiness. Left basal in the lower lobe discrete, not completely sharply demarcated clearing summing with a normal lung parenchyma $(30 \times 30 \mathrm{~mm})$. b) Patient 13 . Computed tomography (native). In the left lung wing, in the lower lobe the architecture of the lung parenchyma is disturbed. In the segment S6, 8, 9, 10 multiple superimposed oval formations, cysts, with air content with diameter individually from $2 \mathrm{~mm}$ to a maximum of $11-12 \mathrm{~mm}$, replace the normal lung parenchyma (total size: $45 \times 24 \times 45 \mathrm{~mm}$ ). Other lung parenchyma with appropriate density and structure. 
Table 2a. Overview of surgical findings in a group of patients.

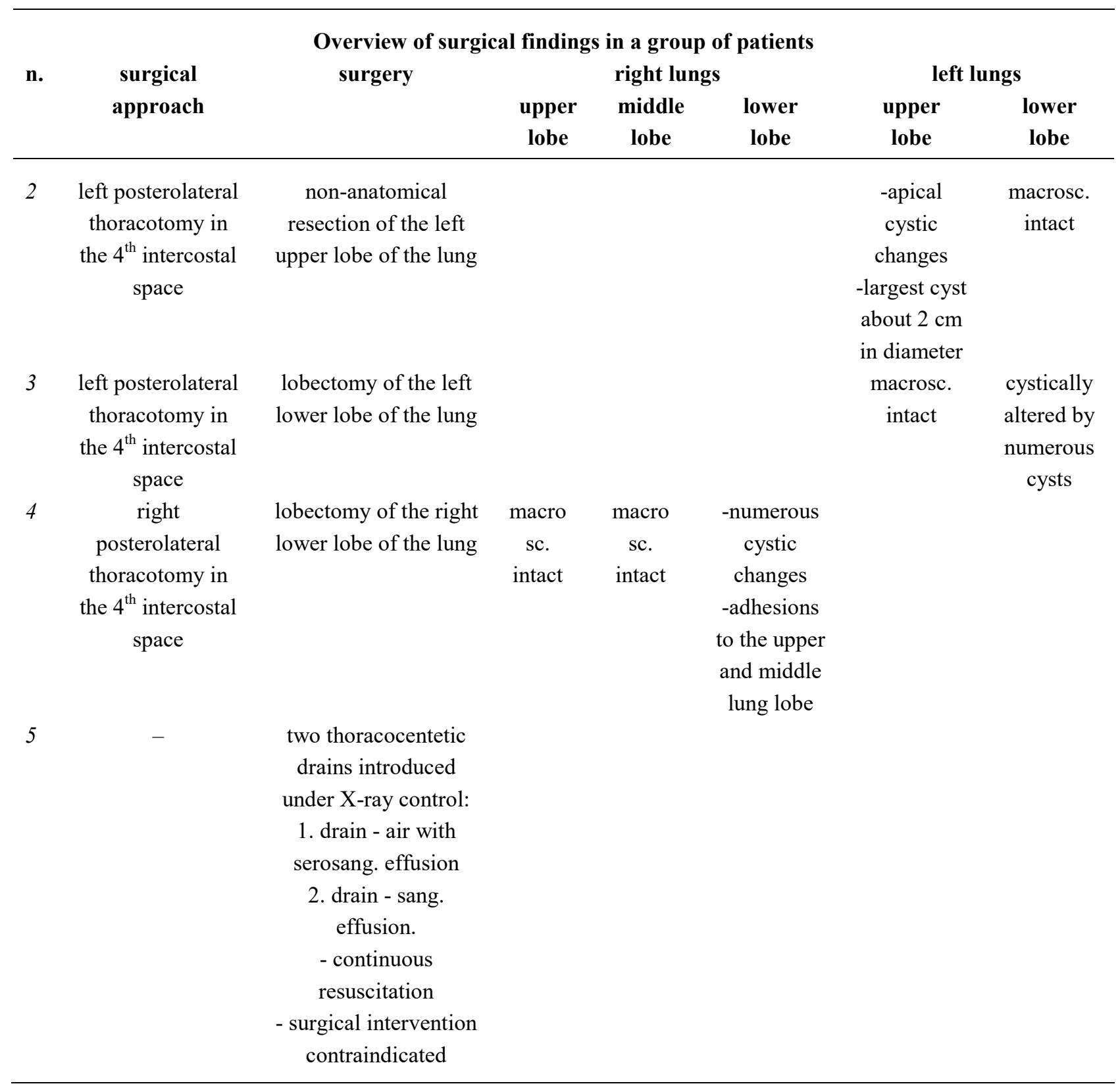

n. - number, macrosc. - macroscopically, pathol. - pathological, serosang. - sanguine, $\mathrm{cm}$ - centimeter

examination superseded the regression of the pathological finding in the lungs) was spontaneously ventilating, without the need for oxygen therapy, with good respiratory mechanics, hemodynamically stable. The initial chest X-ray found a micro-multicystic formation in the middle and lower lung field on the left, without pneumothorax or fluidothorax. Neither the surgeon nor the pulmonologist indicated any intervention. CT was planned at 5 months of age. Patient 9 was hemodynamically stable, on spontaneous ventilation with a slight tendency to tachypnea, but did not require oxygen treatment at admission. Due to the retention of carbon dioxide, respiratory support with Vapotherm for one day was started. On the second day of life she was eupnoic, with adequate ventilationoxygenation parameters. The thorax X-ray showed cystic adenomatoid lung malformation. Due to optimal clinical condition conservative treatment and $\mathrm{CT}$ examination of the lungs at the age of 3 months was recommended. Patient 11 was a 3-hour newborn with prenatally diagnosed congenital cystic lung malformation. Local clarification of the pulmonary parenchyma apically to the right of a size 20x19 mm was seen on thorax X-ray. At the 4-day control, there were only discreet clarifications, 
Table 2b. Overview of surgical findings in a group of patients.

\begin{tabular}{|c|c|c|c|c|c|c|c|}
\hline \multirow{3}{*}{ n. } & \multicolumn{7}{|c|}{ Overview of surgical findings in a group of patients } \\
\hline & \multirow{2}{*}{$\begin{array}{c}\text { surgical } \\
\text { approach }\end{array}$} & \multirow[t]{2}{*}{ surgery } & \multicolumn{3}{|c|}{ right lungs } & \multicolumn{2}{|l|}{ left lungs } \\
\hline & & & $\begin{array}{c}\text { upper } \\
\text { lobe }\end{array}$ & $\begin{array}{c}\text { middle } \\
\text { lobe }\end{array}$ & $\begin{array}{c}\text { lower } \\
\text { lobe }\end{array}$ & $\begin{array}{l}\text { upper } \\
\text { lobe }\end{array}$ & $\begin{array}{l}\text { lower } \\
\text { lobe }\end{array}$ \\
\hline 8 & $\begin{array}{c}\text { left } \\
\text { thoracotomy } \\
\text { in the } 4^{\text {th }} \\
\text { intercostal } \\
\text { space }\end{array}$ & $\begin{array}{l}\text { conservative } \\
\text { non- } \\
\text { anatomical } \\
\text { resection of } \\
\text { the left upper } \\
\text { lung lobe }\end{array}$ & & & & $\begin{array}{l}\text { - a cystically } \\
\text { malformed upper } \\
\text { lobe filled with fluid } \\
\text { and air is expelled } \\
\text { from the surgical } \\
\text { wound under pressure } \\
\text { - it occupies most of } \\
\text { the chest cavity, the } \\
\text { other parenchyma is } \\
\text { suppressed } \\
\text { - from the cranial part } \\
\text { of the upper lobe } \\
\text { about } 35 \text { - } 40 \% \text { is } \\
\text { healthy in appearance }\end{array}$ & $\begin{array}{c}\text { macrosc. } \\
\text { intact }\end{array}$ \\
\hline 10 & $\begin{array}{c}\text { right } \\
\text { thoracotomy } \\
\text { in the } 4^{\text {th }} \\
\text { intercostal } \\
\text { space }\end{array}$ & $\begin{array}{l}\text { lobectomy of } \\
\text { the right upper } \\
\text { lung lobe }\end{array}$ & $\begin{array}{l}\text { - a large cyst } \\
\text { pushing into the } \\
\text { surgical field, } \\
\text { filling and } \\
\text { causing } \\
\text { hemodynamic } \\
\text { instability } \\
\text {... opening and } \\
\text { decompression } \\
\text { were done }\end{array}$ & $\begin{array}{c}\text { without } \\
\text { macrosc. } \\
\text { pathol. } \\
\text { signs }\end{array}$ & $\begin{array}{c}\text { without } \\
\text { macrosc. } \\
\text { pathol. } \\
\text { signs }\end{array}$ & & \\
\hline
\end{tabular}

n. - number, macrosc. - macroscopically, pathol. - pathological

without unambiguous cystic formations. Due to the stabilized clinical condition a surgical intervention was not recommended. CT examination was planned at 6 months of age. Patient 12 was hemodynamically and respiratory stable at admission. On thorax X-ray cystic formation with atelectatic component was shown in the upper lobe of the left pulmonary lobe. For mild dyspnea and minor desaturations, he required respiratory support for a total of one day, without the need for oxygen therapy. On the second day of life a CT angiography of the lungs confirmed the presence of congenital lung malformation. The patient was stable, and the surgeon recommended a conservative procedure with the implementation of a control CT examination of the lungs for a month. Patient 13 upon admission was cardiopulmonary stabilized, on spontaneous ventilation. The initial X-ray showed a picture of wet lungs, without signs of parenchymal pathology, without pneumothorax and fluidothorax. For desaturation to $80 \%$, presence of opening respiratory phenomena and mild dyspnea, supportive treatment with Vapotherm was indicated for a total of 9 hours. In the further course of hospitalization, the patient was already eupneic, with good oxygenation-ventilation parameters. The surgeon recommended only observation and care as in a physiological newborn, rehospitalization at our clinic at the age of 2 months for the purpose of CT examination was recommended.

Gradual improvement of prenatal care, as well as new therapeutic options have significantly affected the 
perinatal survival of patients with pulmonary lesions. Currently, the results describing the management in the neonatal period encounter the problem of small numbers. Care for a patient with a pulmonary lesion is multidisciplinary, has to be in a highly specialized medical facility and needs structure of standardized care (Morini et al. 2018, Witlox 2019).

In all patients from our group the clinical status of the patient was very important and had an influence on decision of the therapeutic plan. Even achievement of optimal level of maturity and mastering postnatal adaptation does not preclude surgery. The surgeon must always consider all possible risks arising from a finding in the pulmonary parenchyma. We believe that the presented results, as well as the findings on thorax x-rays and CT angiography from our workplace, will supplement the information on the clinical condition of newborns with prenatally diagnosed congenital pulmonary malformations and contribute to expanding knowledge and refining algorithms for caring for this risk group of newborns.

\section{Conflict of Interest}

There is no conflict of interest.

\section{Acknowledgements}

The study was partly supported by the Slovak Grant Agency VEGA (grant No. 2/0166/20 and No. 2/0154/20).

\begin{abstract}
Abbreviations
CAPM - congenital airway pulmonary malformation, CCAPM - congenital cystic adenomatoid malformation, CPM - congenital pulmonary malformations, CT computed tomography, MRI - magnetic resonance imaging, RI - respiratory insufficiency.
\end{abstract}

\section{References}

ADZICK NS, HARRISON MR, GLICK PL, GOLBUS MS, ANDERSON RL, MAHONY BS, CALLEN PW, HIRSCH JH, LUTHY DA, FILLY RA, DELORIMIER AA: Fetal cystic adenomatoid malformation: prenatal diagnosis and natural history. J Pediatr Surg 20: 483-488, 1985. https://doi.org/10.1016/S0022-3468(85)80470-X

ANDRADE CF, FERREIRA HP, FISCHER GB: Congenital lung malformations. J Bras Pneumol 37: 259-271, 2011. https://doi.org/10.1590/S1806-37132011000200017

ANNUNZIATA F, BUSH A, BORGIA F, RAIMONDI F, MONTELLA S, POETA M, BORRELLI M, SANTAMARIA F: Congenital lung malformations: unresolved issues and unanswered questions. Front Pediatr 7: 239, 2019. https://doi.org/10.3389/fped.2019.00239

BERROCAL T, MADRID C, NOVO S, GUTIÉRREZ J, ARJONILLA A, GÓMEZ-LEÓNE N: Congenital anomalies of the tracheobronchial tree, lung, and mediastinum: embryology, radiology, and pathology. Radiographics 24 : e17, 2004. https://doi.org/10.1148/rg.e17

BOUCHARD S: To cut or not to cut? what is the role of surgery in the management of pediatric lung lesions [online]. 2018, https://cts-sct.ca/wp-content/uploads/2018/04/Bouchard-S.pdf

BULAS DI, EGLOFF A: Prenatal diagnosis and management of bronchopulmonary sequestration. UpToDate. 2019. https://www.uptodate.com/contents/prenatal-diagnosis-and-management-of-bronchopulmonary-sequestration.

CAVORETTO P, MOLINA F, POGGI S, DAVENPORT M, NICOLAIDES KH: Prenatal diagnosis and outcome of echogenic fetal lung lesions. Ultrasound Obstet Gynecol 32: 769, 2008. https://doi.org/10.1002/uog.6218

CH'IN KY, TANG MY: Congenital adenomatoid malformation of one lobe of a lung with general anasarca. Arch Pathol 48: 221-229, 1949.

CHON AH, STEIN JE, GERSTENFELD T, WANG L, VAZQUEZ WD, CHMAIT RH: The use of fetal bronchoscopy in the diagnosis and management of a suspected obstructive lung mass. AJP Rep 8: e195-e200, 2018. https://doi.org/10.1055/s-0038-1673378

COSTA AS JR, PERFEITO JA, FORTE V: Surgical treatment of 60 patients with pulmonary malformations: what have we learned? J Bras Pneumol 34: 661-666, 2008. https://doi.org/10.1590/S1806-37132008000900005

D'EUFEMIA MD, CIANCI S, Di MEGLIO F, Di MEGLIO L, Di MEGLiO L, VITALE SG, LAGANÀ AS, CHIOFATO B, RAPISARDA AMCH, PADULA F, LA ROSA V, COCO C, VASCONE C: Congenital high airway obstruction syndrome (CHAOS): discussing the role and limits of prenatal diagnosis starting from a single-center case series. J Prenat Med 10: 4-7, 2016. https://doi.org/10.11138/jpm/2016.10.1.004 
EGLOFF A, BULAS DI: Congenital pulmonary airway malformation: Prenatal diagnosis and management. UpToDate. March 4 2020. https://www.uptodate.com/contents/congenital-pulmonary-airway-malformation-prenataldiagnosis-and-management

HARMATH Á, CSABA E, HAUZMAN J, HAJDÚ B, PAPP Z: Congenital lung malformations in the second trimester: prenatal ultrasound diagnosis and pathologic findings. J Clinical Ultrasound 35: 250-255, 2007. https://doi.org/10.1002/jcu.20341

KAPELLER K, POSPÍŠILOVÁ V: Embryology of the human body. Osveta, K. Kappeler, V. Pospíšilová (Eds.) 1991, p 341.

MORINI F, ZANI A, CONFORTI A, VAN HEURN E, EATON S, PURI P, RINTALA R, LUKAC M, KUEBLER JF, FRIEDMACHER F, WIJNEN R, TOVAR JA, PIERRO A, BAGOLAN P: Current Management of Congenital Pulmonary Airway Malformations: A "European Pediatric Surgeons' Association" Survey. Eur J Pediatr Surg 28: e1-e1, 2018. https://doi.org/10.1055/s-0038-1660778

MRÁZ P, BINOVSKÝ A, HOLOMÁŇOVÁ A, OSVALDOVÁ M, RUTTKAY-NEDECKÁ E: Anatomy of the human body I. SAP, P. Mráz (Ed.), Bratislava, 2015, p527.

OERMANN CHM, GARCIA-PRATS JA, REDDING G, HOPPIN AG: Congenital pulmonary airway (cystic adenomatoid) malformation. UpToDate. 2019. https://www.uptodate.com/contents/congenital-pulmonaryairway-cystic-adenomatoid-malformation?search=cystic\%20adeno

PIEŠOVÁ M, MACH M: Impact of perinatal hypoxia on the developing brain. Physiol Res 69: 199-213, 2020. https://doi.org/10.33549/physiolres.934198

SADLER TW: Langman's medical embryology. GRADA, 10th edition. 2011.p414.

STOCKER JT, MADEWELL JE, DRAKE RM: Congenital cystic adenomatoid malformation of the lung. Classification and morphologic spectrum. Hum Pathol 8: 155-171, 1977. https://doi.org/10.1016/S00468177(77)80078-6

SWARR DT, PERANTEAU WH, POGORILER J, FRANK JB, ADZICK SN, HEDRICK HL, MORLEY M, ZHOU S, MORRISEY EE: Novel molecular and phenotypic insights into congenital lung malformations. Am J Respir Crit Care Med 197: 1328-1339, 2018. https://doi.org/10.1164/rccm.201706-12430C

WITLOX RS, LOPRIORE E, OEPKES D: Prenatal interventions for fetal lung lesions. Prenat Diagn 31: 628-636, 2011. https://doi.org/10.1002/pd.2778

WITLOX RSGM: Short- and long-term outcome after fetal therapy for thoracic abnormalities. Leiden University, the Netherlands 2019. p168. 